J. Perinat. Med. $11(1983) 200$

\section{Comparative mortality and morbidity of infants transferred in utero or postnatally}

\section{Introduction}

In 1978, the Liason Committee of the British Paediatric Association and the Royal College of Obstetricians and Gynaecologists [3] recommended that mothers in danger of delivering preterm should be transferred antenatally to a centre with neonatal intensive care facilities. Since that time, others have echoed this recommendation $[2,6]$. This study compares the mortality and morbidity of infants transferred in utero with those transferred neonatally to a referral center for obstetric and neonatal intensive care.

\section{Patients and methods}

Between 1st August, 1979 and 31st January, 1982 , two hundred and six women were delivered of 218 infants after transfer to Hammersmith Hospital during the antenatal period. All infants were delivered before 34 completed weeks of pregnancy as measured by the last normal menstrual period and fetal biparietal measurements, and verified by DUBOWITZ [4] gestational assessment neonatally. Six infants had lethal congenital abnormalities which have been excluded from the study. Of the remaining 212 infants, 155 were transferred because of spontaneous preterm labor, 52 because of severe pregnancy induced hypertension with proteinuria and 5 because of

\section{Curriculum Vitae}

RONALD LAMONT was born in Scotland in 1952. He studied medicine at the University of Edinburgh. He specialised in Obstetrics and Gynaecology in the University of Edinburgh and at the Institute of Obstetrics and Gynaecology at Hammersmith Hospital, London where he has been working since 1979. His main interest is preterm labour and delivery.

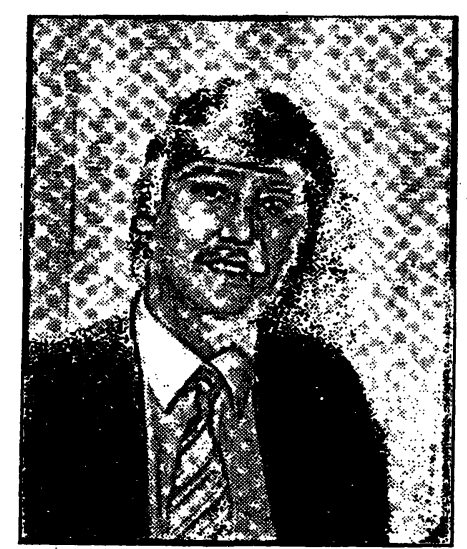

antepartum hemorrhage or severe intrauterine growth retardation. After excluding fetal abnormality and infants transferred for surgical correction of congenital abnormality, 166 infants born between 26 and 34 completed weeks of pregnancy were transferred neonatally during the same period. The mean ( \pm 1 S.D.) values for gestational age and birthweight of the two groups were almost identical (Tab. I and II). Survival in the two groups was measured by the number of babies discharged home directly or via the neonatal unit of the referring hospital. Short term morbidity was measured by the presence of intraventricular hemorrhage (IVH) detected ultrasonically as described by LEVENE et al. [5]. No mother delivered in transit, and all infants were alive on arrival. 
Tab. I. Percentage survival by birthweight.

\begin{tabular}{lccl}
\hline Birthweight & $\begin{array}{l}\text { Neonatal } \\
\text { transfer } \\
\mathrm{n}=166\end{array}$ & $\begin{array}{l}\text { In utero } \\
\text { transfer } \\
\mathrm{n}=212\end{array}$ & $\begin{array}{l}\text { Signif- } \\
\text { icance }\end{array}$ \\
\hline (mean \pm 1 S.D.) & $1398 \pm 436$ & $1391 \pm 415$ & N.S. \\
$<1000 \mathrm{~g}$ & $48(29)$ & $47(38)$ & N.S. \\
$1000-1499 \mathrm{~g}$ & $69(77)$ & $86(92)$ & $<0.01$ \\
$1500-1999 \mathrm{~g}$ & $81(42)$ & $95(66)$ & $<0.02$ \\
$>2000 \mathrm{~g}$ & $94(18)$ & $100(16)$ & N.S. \\
Less than $1500 \mathrm{~g}$ & $63(106)$ & $75(130)$ & $<0.1$ \\
$1500 \mathrm{~g}$ and over & $85(60)$ & $96(82)$ & $<0.02$ \\
Total & $70(166)$ & $83(212)$ & $<0.01$ \\
\hline
\end{tabular}

$n=()$

Tab. II. Percentage survival by gestational age.

\begin{tabular}{llll}
\hline Gestational age & $\begin{array}{l}\text { Neonatal } \\
\text { transfer }\end{array}$ & $\begin{array}{l}\text { In utero } \\
\text { transfer }\end{array}$ & $\begin{array}{l}\text { Signif- } \\
\text { icance }\end{array}$ \\
\hline (mean \pm 1 S.D.) & $29.9 \pm 2.2$ & $29.9 \pm 2.1$ & N.S. \\
26 and 27 & $46(28)$ & $39(23)$ & N.S. \\
28 and 29 & $49(47)$ & $71(58)$ & $<0.05$ \\
30 and 31 & $92(38)$ & $94(63)$ & N.S. \\
32 and 33 & $89(53)$ & $99(68)$ & $<0.05$ \\
$26-29$ & $48(75)$ & $62(81)$ & $<0.001$ \\
$30-33$ & $90(91)$ & $96(131)$ & $<0.1$ \\
Total & $70(166)$ & $83(212)$ & $<0.01$ \\
\hline
\end{tabular}

$\mathrm{n}=(\quad)$

\section{Results}

Survival by birthweight and gestational age is shown in Tabs. I and II respectively. The incidence of intraventricular hemorrhage by birthweight and gestational age is shown in Tabs. III and IV respectively.

Tab. III. Percentage intraventricular hemorrhage by birthweight of infants screeded.

\begin{tabular}{llll}
\hline Birthweight & $\begin{array}{l}\text { Neonatal } \\
\text { transfer }\end{array}$ & $\begin{array}{l}\text { In utero } \\
\text { transfer }\end{array}$ & $\begin{array}{l}\text { Signif- } \\
\text { icance }\end{array}$ \\
\hline$<1000 \mathrm{~g}$ & $50(20)$ & $62(34)$ & N.S. \\
$1000-1499 \mathrm{~g}$ & $47(60)$ & $33(89)$ & $<0.01$ \\
$1500-1999 \mathrm{~g}$ & $43(30)$ & $15(66)$ & $<0.1$ \\
$>2000 \mathrm{~g}$ & $33(9)$ & $11(18)$ & N.S. \\
less than $1500 \mathrm{~g}$ & $48(80)$ & $41(123)$ & N.S. \\
$1500 \mathrm{~g}$ and over & $41(39)$ & $14(84)$ & $<0.001$ \\
Total & $45(119)$ & $30(207)$ & $<0.01$ \\
\hline
\end{tabular}

$\mathrm{n}=(\quad)$
Tab. IV. Percentage intraventricular hemorrhage by gestational age per infants screened.

\begin{tabular}{llll}
\hline $\begin{array}{l}\text { Mean gestational } \\
\text { age (weeks) }\end{array}$ & $\begin{array}{l}\text { Neonatal } \\
\text { transfer }\end{array}$ & $\begin{array}{l}\text { In utero } \\
\text { transfer }\end{array}$ & $\begin{array}{l}\text { Signif- } \\
\text { icance }\end{array}$ \\
\hline 26 and 27 & $50(22)$ & $63(19)$ & N.S. \\
28 and 29 & $57(35)$ & $46(61)$ & N.S. \\
30 and 31 & $37(30)$ & $17(54)$ & $<0.05$ \\
32 and 33 & $38(32)$ & $18(73)$ & $<0.05$ \\
$26-29$ & $54(57)$ & $50(80)$ & N.S. \\
$30-33$ & $37(62)$ & $17(127)$ & $<0.01$ \\
Total & $45(119)$ & $30(207)$ & $<0.01$ \\
\hline
\end{tabular}

$n=(\quad)$

Survival among infants transferred in utero and especially those whose birthweights were between $1000 \mathrm{~g}$ and $1999 \mathrm{~g}$ and whose gestational age was between 26 and 29 weeks, was significantly higher than among infants of comparable birthweight and gestational age who were transferred after delivery. Intraventricular hemorrhage was significantly less in the in utero transfer group, especially among infants weighing over $1500 \mathrm{~g}$ or of more than 30 weeks gestation.

\section{Discussion}

Neonatal intensive care has been shown to improve neonatal survival [7] and transfer of a sick neonate to a centre with intensive care facilities also improves survival [1]. Comparing neonatal transfer with in utero transfer to show improved outcome is difficult since the groups are not strictly comparable. In utero transfers are a selected high-risk group, but not all will require intensive neonatal care. Neonatal transfers are selected by severity of disease, but by their very nature exclude stillbirths and very early neonatal deaths. Postnatal transfer carries risks for the neonate during transit, such as hypothermia. Monitoring of color, respiration and heart rate are difficult because of noise, vibration and poor access to the infant with blankets and silver swaddlers for protection against hypothermia. Ventilatory requirements can only be assessed clinically, without the benefits of blood gas analysis. Intubation or re-intubation in transit can also be difficult and hazardous.

In this study, neonatal management did not differ since all infants were admitted to the neonatal unit 
during the same period of time. The birthweight and gestational age of each group was similar. If it is assumed that all the in utero transfers had been born live in the referring hospital and transferred neonatally, they can then be submitted to the observed birthweight specific perinatal mortality of the neonatally transferred group. Using this crude standardisation, it is to be expected that 63 infants would have died if transferred neonatally. Actually, 36 of these infants died after in utero transfer, a difference of 27 deaths. Using the same standardisation, we would predict that 31 infants were protected from IVH by in utero transfer. Long term follow up is necessary to assess the significance of IVH, but we conclude that in utero transfer significantly reduces mortality and morbidity associated with neonatal transfer.

It can be seen from Tabs. I-IV that infants transferred in utero and delivered in the regional referral center, had a significantly improved survival rate and significantly less IVH than those infants transferred neonatally.

\section{Summary}

The outcome of two hundred and twelve infants transferred in utero and delivered in the regional neonatal intensive care center is compared with one hundred and sixty-six infants born elsewhere and transferred neonatally to the same unit, during the same period of time. The mean birthweight ( \pm 1 S.D.) was $1391 \mathrm{~g}( \pm 415 \mathrm{~g}$ ) for the infants transferred in utero, and $1398 \mathrm{~g}( \pm 415 \mathrm{~g})$ for the infants transferred neonatally. The mean gestational age of the two groups was 29.9 completed weeks for both groups.

Survival was defined as discharge from the neonatal unit and intraventricular hemorrhage was diagnosed ultrasonically. The survival rate was $83 \%$ for the group trans-

ferred in utero and $70 \%$ for the group transferred postnatally $(p=<0.01)$. The incidence of intraventricular hemorrhage was $30 \%$ and $45 \%$ respectively $(p=<0.01$ ).

Using birthweight specific perinatal mortality rates and intraventricular hemorrhage rates of the neonatally transferred group for standardisation, it can be calculated that 27 infants survived and 31 were protected from intraventricular hemorrhage because of in utero transfer.

It is concluded that infants likely to require neonatal intensive care have decreased mortality and morbidity if transferred in utero to a center with these facilities rather than being transferred neonatally.

Keywords: Intraventricular hemorrhage, in utero transfer, neonatal transfer, preterm delivery, survival.

\section{Zusammenfassung}

Vergleich der Mortalität und Morbidität bei in utero bzw. postnatal verlegten Neugeborenen

In unserer Untersuchung haben wir den Zustand von 212 Kindern, die in utero in ein regionales Krankenhaus mit einer Neugeborenen-Intensivstation kamen und dort geboren wurden, verglichen mit dem von 166 Kindern, die in dem gleichen Zeitraum außerhalb dieses Krankenhauses geboren wurden und postnatal auf die gleiche Intensivstation gebracht wurden.

Das mittlere Geburtsgewicht ( \pm 1 Standardabweichung) betrug für die in utero eingewiesenen Neugeborenen $1391 \mathrm{~g}( \pm 415 \mathrm{~g})$ und für die postnatal verlegten Neugeborenen $1398 \mathrm{~g}( \pm 415 \mathrm{~g})$. Die mittlere Schwangerschaftsdauer ( \pm 1 Standardabweichung) lag in beiden Gruppen bei 29,9 Wochen $( \pm 2,2$ Wochen).

Als Überlebende galten die Kinder, die von der Intensivstation entlassen wurden. Intraventrikuläre Blutungen wurden ultrasonographisch diagnostiziert. In der Gruppe der in utero eingewiesenen Kinder betrug die Überlebensrate $83 \%$, bei den postnatal verlegten Neugeborenen $70 \%$ $(p \leqslant 0,01)$. Die Inzidenz von intraventrikulären Blutungen lag bei $30 \%$ bzw. $45 \%(p \leqslant 0,01)$.

Setzt man geburtsgewichtsspezifische perinatale Mortalitätsraten und die Rate von intraventrikulären Blutungen bei postnatal verlegten . Neugeborenen zur Standardisierung ein, so läßt sich berechnen, daß 27 Kinder eine intraventrikuläre Blutung überlebten und 31 Kinder vor einer intraventrikulären Blutung bewahrt wurden, weil sie bereits in utero eingewiesen wurden.

Wir schließen daraus, daß Neugeborene, die wahrscheinlich einer neonatalen Intensivüberwachung bedürfen, eine herabgesetzte Mortalität und Morbidität haben, wenn sie in utero an ein Zentrum mit entsprechenden Möglichkeiten überwiesen werden und nicht erst postnatal verlegt werden.

Schlüsselwörter: Verlegung in utero, intraventrikuläre Blutung, neonatale Verlegung, Überlebenschance, vorzeitige Entbindung. 


\section{Résumé}

Mortalité et morbidité comparatives des enfants transférés in utéro ou après la naissance

Le devenir de 212 enfants transférés in utéro et nés au centre intensif néonatal régional est comparé avec celui de 166 enfants nés ailleurs et transféres après la naissance dans la même unité, pendant la même période.

Le poids de naissance moyen $( \pm 1 \mathrm{DS})$ des enfants transférés in utéro est de $1391 \mathrm{~g}( \pm 415 \mathrm{~g})$, et de $1398 \mathrm{~g}$ $( \pm 415 \mathrm{~g})$ pour les enfants transférés après la naissance. L'âge gestationnel moyen de deux groupes ( \pm 1 DS) est de 29,9 semaines $( \pm 2,2)$.

La survie a été définie comme le départ de l'unité de néonatologie et les hémorragies intraventriculaires ont été diagnostiquées par ultra-sons. Le taux de survivants est de $83 \%$ pour le groupe transféré in utéro et de $70 \%$ pour le groupe transféré après la naissance $(P<0,01)$. L'incidence des hémorragies intraventriculaires est respectivement de $30 \%$ et de $45 \%(P<0,01)$.

On peut calculer que 27 enfants ont survécu et que 31 ont été protégés d'une hémorragie intraventriculaire du fait du transfert in utéro, si l'on se fonde sur les taux de mortalité périnatale spécifique du poids de naissance et des hémorragies intraventriculaires chez les enfants transférés après la naissance.

En conclusion, les enfants qui vont nécessiter vraisemblablement des soins intensifs néonataux ont une diminution de la mortalité et de la morbidité si leur transfert dans un centre équipé est effectudé in utéro par rapport à ceux transférés dans la période néonatale.

Mots-clés: Accouchement prématuré, hémorragie intraventriculaire, survie, transfert in utéro, transfert néo-natal.

Acknowledgement: We are grateful to Glaxo Limited for supplying fellowships for R. F. LAMONT, P. D. M. DUNLOP and P.CROWLEY.

\section{Bibliography}

[1] BLAKE, A. M., N. MCINTOSH, E. O. REYNOLDS: Transport of newborn infants for intensive care. Brit. Med. J. 4 (1975) 13

[2] BLAKE, A. M., M. J. POLlITZER, E. O. R. REYNOLDS: Referral of mothers and infants for intensive care. Brit. Med.J. 2 (1979) 414

[3]BRITISH PAEDIATRIC ASSOCIATION/Royal College of Obstetricians and Gynaecologists Liason Committee: Recommendations for the improvement of infant care during the perinatal period. (1978)

[4] DUBOWITZ, 'L. M. S., V. DUBOWITZ, C. GOLDBERG: Clinical assessment of gestational age in the newborn infant. J. Pediat. 77 (1970) 1

[5] LEVENE, M. I., J. S. WIGGLESWORTH, V. DUBOWITZ: Cerebral structure and intraventricular haemorrhage in the neonate: A real-time ultrasound study. Arch. Dis. Childh. 56 (1981) 416
[6] MODANLOU, H. D., W. DORCHESTER, R. K. FREEMAN, C. ROMMALL: Perinatal transport to a regional perinatal centre in a metropolitan area. Maternal versus neonatal transport. Amer. J. Obstet. Gynec. 138 (1980) 1157

[7]STEWART, A. L., E. O. R. REYNOLDS: Intensive care and the very low birthweight baby. Lancet 2 (1979) 846

Received December 13, 1982. Accepted March 16, 1983.

Dr. Ronald F. Lamont

Dept. of Human Reproduction and Obstetrics,

Princess Anne Hospital, Coxford Road, Southhampton, S09 4HA/GB 